\title{
L'impronta della dinamica storica dell'insediamento di frontiera: l'Epte in Normandia, Francia
}

\author{
Marta Zerbini
}

Abstract

All'interno di un filone di ricerca che interroga la mutazione della forma, si propone l'analisi e la lettura di un territorio e delle città che lo abitano, lavorando nella prospettiva di identificare procedure e tipologie di intervento che, succedutesi nel tempo, lo hanno trasformato fino a definirne la conformazione attuale.

Il disegno diviene strumento per rintracciare queste incongruenze, testimoni della trasformazione del territorio, indagandone la natura ed interrogandone la forma.

Presentiamo in questa sede lo studio della frontiera fortificata lungo il fiume Epte, in Francia: un sistema territoriale che nasce come serie di fortificazioni, si sviluppa in borghi, ed infine è trasformato sotto l'influenza di una città forte, Parigi. Si analizza da ciò il processo di urbanizzazione che lega questi tre elementi (castello, borgo e città nuova) lungo un viaggio nel tempo e nella storia attraverso il disegno urbano. Con questa proposta di lettura si pone l'accento sulla trasformazione che awiene in un territorio in cui, nonostante si conservi ancora nel tessuto una forte identità storica, è così predominante l'influenza di un centro forte esterno da modificarne la maglia urbana.

II contributo mette al centro il Disegno per leggere e comprendere fenomeni di sviluppo urbano, aprendo la via a più ampie riflessioni ti dopo contemporaneo sul come progettare all'interno di questi territori e secondo quale modalità agire per calmierare o piuttosto amplificare certi sviluppi.

Parole chiave

frontiera fortificata, Epte, Normandia, castelli, fenomeni di espansione urbana.

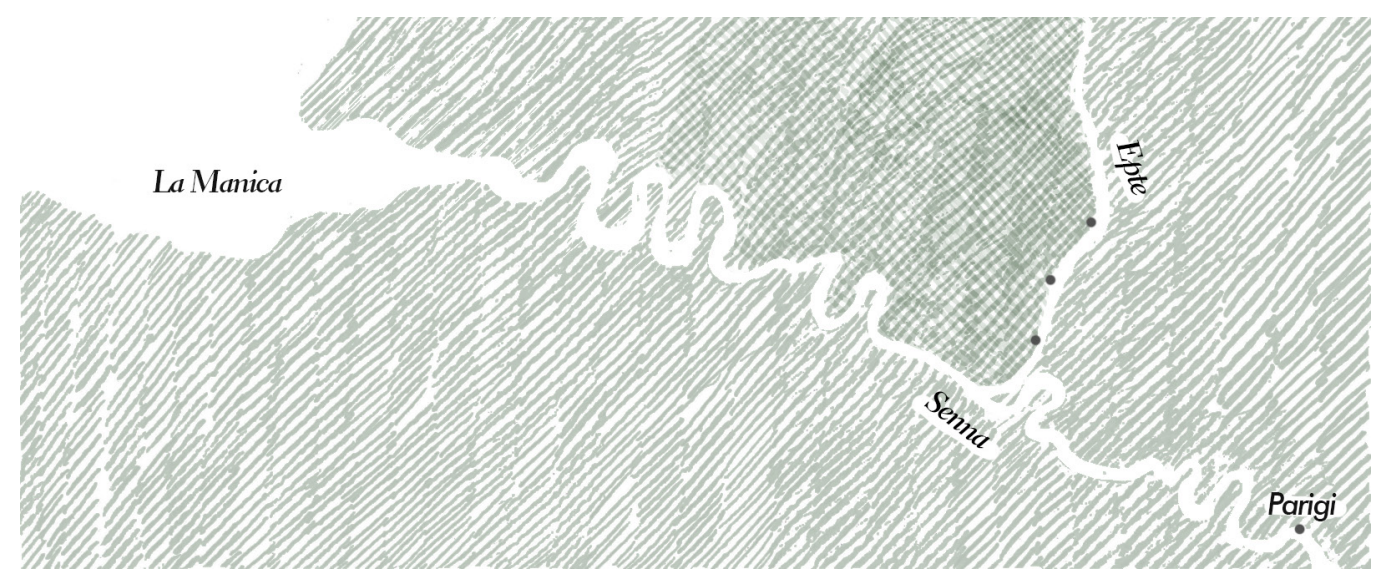




\section{Introduzione}

Lo studio si inserisce in una linea di ricerca aperta all'interno del seminarioVille et territories entre memoire et actualité svolto presso l'Ecole Nationale Superiéure d'Architecture di Paris Val De Seine [I].

Il nome stesso del seminario Città e territori tra memoria e attualità rimanda al concetto di evoluzione temporale che caratterizza un luogo, facendo presupporre quindi alla sua trasformazione storica.

II tema centrale è quindi la città, analizzata a diverse scale ed in diverse epoche, affrontata dal punto di vista dei processi di trasformazione che l'hanno interessata.

Tra i fenomeni di 'metropolizzazione' internazionale in piena espansione e le piccole città ancora rurali in stato di svuotamento progressivo, ci si interroga sul come comprendere nella nostra contemporaneità la dimensione urbana.

Come progettare all'interno di questi territori e secondo quale modalità agire per calmierare o piuttosto amplificare certi sviluppi?

Si apre un grande dibattito, più che attuale, riguardo la trasformazione di realtà storiche, villaggi, città e territori, sotto la forte influenza esercitata dai recenti fenomeni di espansione metropolitana.

Una questione ed una problematica che se da un lato è interessante studiare con il disegno ed approfondire con il rilievo, dall'altra si apre a problematiche interdisciplinari che riguardano tutta l'architettura. Sulla scorta delle considerazioni mosse possiamo parlare quindi di una linea di ricerca di interesse multidisciplinare ed internazionale.

Se consideriamo la città come essa stessa il risultato del tempo che ha vissuto, degli uomini che l'hanno costruita e delle culture che l'hanno abitata, è proprio nella sua stratificazione, espansione, o elisione, che si rintracciano le linee del suo passato e della sua storia.

Le tracce delle azioni che hanno trasformato le città ed i loro territori, partendo da quelle di fondazione fino ad arrivare a quelle che ne hanno determinato la conformazione attuale,

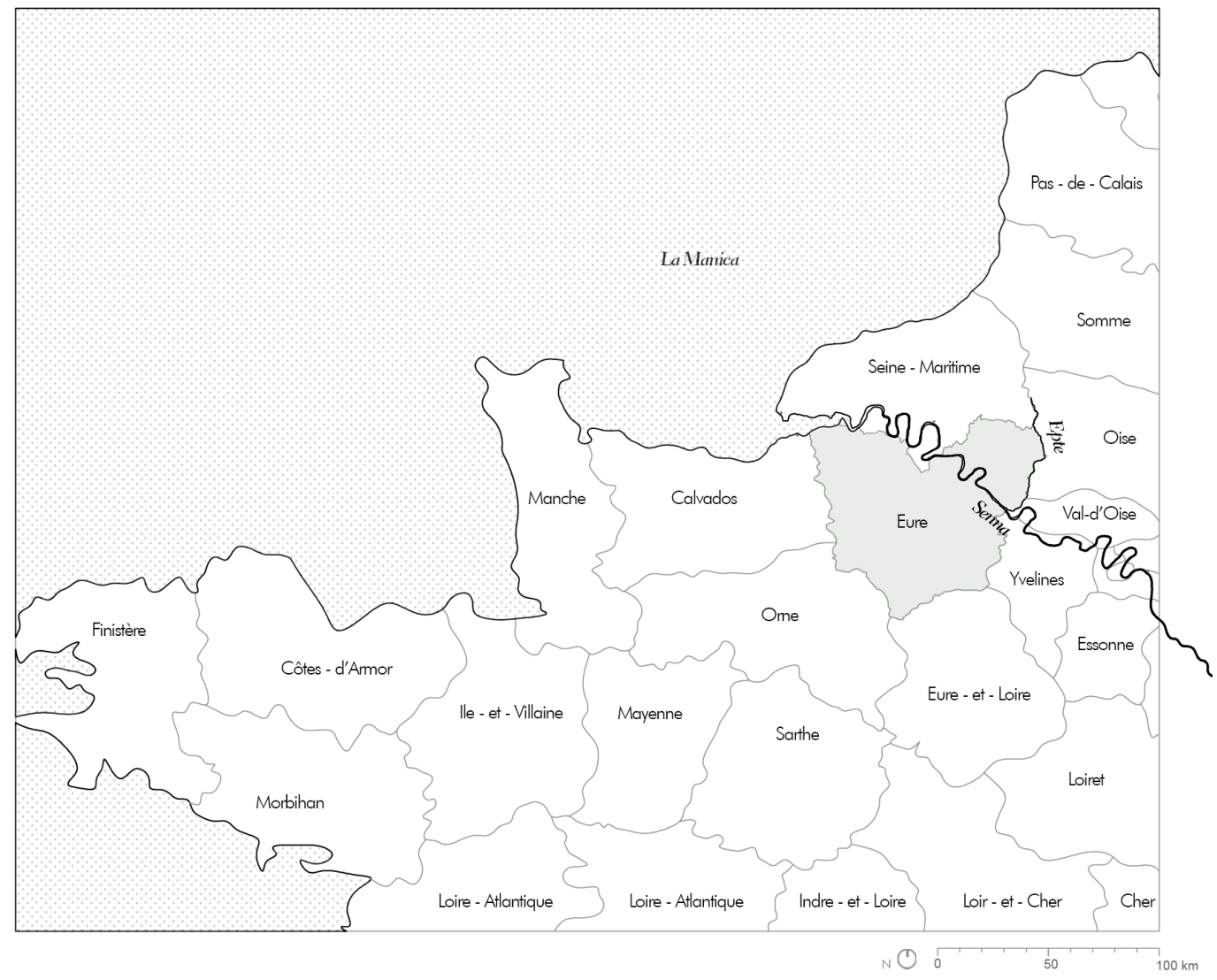


sono identificabili attraverso matrici urbane e geometriche: leggendole nel tempo, talvolta confermate $\circ$ talvolta tradite, segnano la strada alla comprensione della mutazione delle città o dei territori presi in esame.

II disegno, grazie alla sua potenzialità critica ed analitica, è lo strumento che ci permette di rintracciare queste incongruenze testimoni della trasformazione territoriale, e lo presentiamo in questa sede applicato ad un caso studio specifico: la frontiera fortificata dell'Epte. Per entrare nel vivo dell'analisi si riconoscono dapprima gli elementi da studiare che compongono il sistema, in questo caso un sistema territoriale puntiforme a 3 centri che nasce come fortificazione, si sviluppa come villaggio, ed infine subisce l'influenza di una città forte, e si analizza poi il processo di urbanizzazione che lega i tre elementi in una relazione di forma tra sistema a rete territoriale e sistema centrale.

Fig. 2. Inquadramento territoriale del dipartimento dell'Eure in relazione 'Epte e alle città principali del territorio.

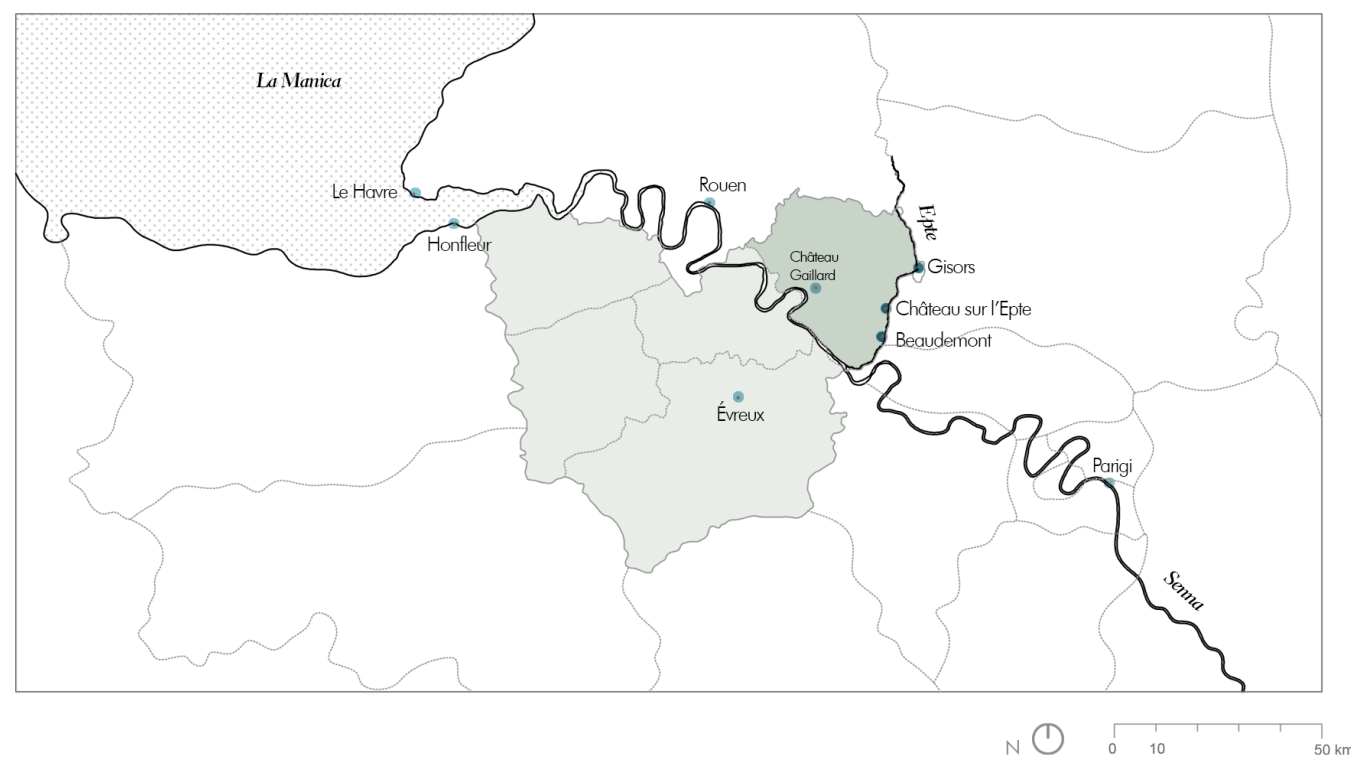

\section{La frontiera fortificata dell'Epte: contesto geografico e storico}

Si introduce il caso studio della ricerca collocandolo e presentandolo nel suo contesto geografico e storico. La riviera Epte, affluente del fiume Senna, scorre a nord-ovest di Parigi, nasce nel comune di Compainville, dipartimento di Seine-Maritime in Normandia, e prosegue verso sud. Attraversando città come Gisors, Saint Clair sur Epte, Château sur Epte, Gasny e Giverny, la riviera Epte marca per la sua totalità il confine tra Normandia ad ovest e Hauts-de-France e l'lle de France ad est [Bini 2005, pp 6-23] (fig. I).

Risulta evidente quindi come questo elemento naturale marchi in maniera significativa il territorio circostante, e come sia proprio la sua conformazione geografica a determinare la trasformazione del paesaggio, e quindi, la sua valenza strategica (fig. 2).

La rilevanza dell'affluente Epte nella storia risale al $X$ secolo, quando, nel rappresentare un limes naturale tra il territorio abitato dai normanni e quello popolato dai francesi, la sua posizione strategica l'ha resa delle frontiere più contese nella storia del XI secolo tra la corona inglese e quella francese (figg. 3-5).

Già nella geografia storica del $X$ secolo infatti questo corso d'acqua segnava il confine naturale tra il Vexin Normanno e il Vexin Francese e per la lunghezza del suo corso era costellato puntualmente da fortificazioni minori appartenenti a conti normanni.

Vista l'ambigua fedeltà politica che i conti normanni nutrivano nei confronti delle due corone, quella inglese e quella francese, il re d'Inghilterra Enrico I decise di costruirvi una serie di fortezze e castelli sotto suo diretto controllo, permettendo al popolo normanno di continuare a vivere nel territorio in cambio di manodopera e materiali da costruzione 
[Bini 2005, pp 57-64]. Attraverso questa operazione di edificazione per mano della corona inglese, l'affluente Epte si trasforma in una vera e propria frontiera fortificata che separa il ducato di Normandia dal resto del territorio di dominio francese.

A testimoniare l'importanza ricoperta da questo luogo nel passato e la frontiera che esso rappresentava, ancora ad oggi il fiume continua ad adempiere alla funzione di limite nei nuovi confini dipartimentali del territorio francese.

Gli incastellamenti che per difesa del territorio hanno popolato il corso del fiume sono ad oggi in buona parte ancora rintracciabili nei borghi medievali e nei villaggi che li hanno abitati, ereditando, a conferma di ciò, anche il nome stesso (fig. 6).

In una successione temporale e storica, gli stessi borghi e villaggi si sono espansi sviluppandosi attorno ai cestelli, ingrandendosi, fino a modificare il proprio orientamento urbano, piegato sotto la forza centripeta di Parigi metropoli che attira a sé radialmente le città intorno.

Fig. 3. Guillaume Delisle, Carte de Normandie, 1716, Bibliothèque Nationale de France, département Cartes et plans, GE DD2987 (448 B): <https:// gallica.bnf.fr/ark://2148/ btvlb53052675v>.

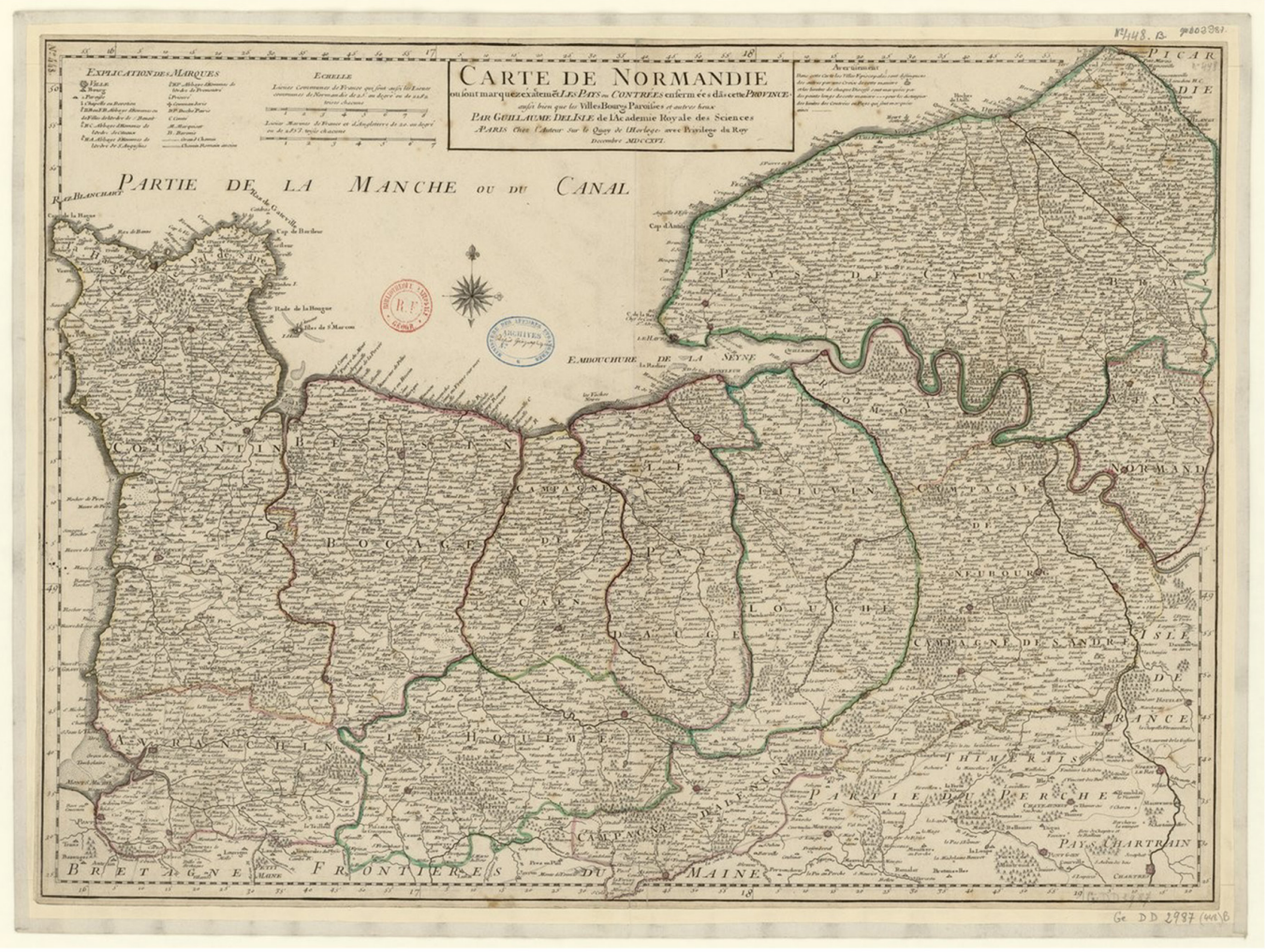

Source gallica.bnf.fr / Bibliothèque nationale de France

\section{Fortificazioni e città-castello sulla riviera dell’Epte}

Spiegato quello che è l'iter logico che delinea le tappe del percorso di conformazione e trasformazione del confine fortificato normanno, si scelgono dei casi studio specifici su cui approfondire le analisi e dimostrare quanto posto in tesi.

I casi studio consistono nei singoli centri urbani che affiorano lungo l'Epte e che sono accomunati tra loro dalle medesime caratteristiche territoriali.Tutte le fortificazioni analizzate sorgono sullo stesso tipo di morfologia territoriale, con la fortificazione a monte e lo sviluppo urbano a valle, la loro edificazione è databile negli stessi periodi storici e sono tutti costruititi dalla stessa manodopera locale, condividendo tra loro storia e cultura.

Comparando i diversi casi studio emergono analogie e regole che permettono di studiare il limes come barriera e come fronte unitario, facendo notare come si sia trasformato nella storia e come, allo stesso tempo, proprio questi cambiamenti abbiano lasciato tracce fisiche nelle città. 
Fig. 4. Guillaume Delisle, Carte de Normandie, 17 I6, dettaglio: raffigurazione del Vexin Normanno, Bibliothèque Nationale de France, département Cartes et plans, GE DD$2987(448$ B): $<$ https//

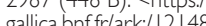
btvlb53052675v

Fig. 5. Rielaborazione della cartografia storica rappresentante la regione del Vexin Normanno, con riferimento alliidrografia del territorio, alle città più importanti e a quelle prese in esame.
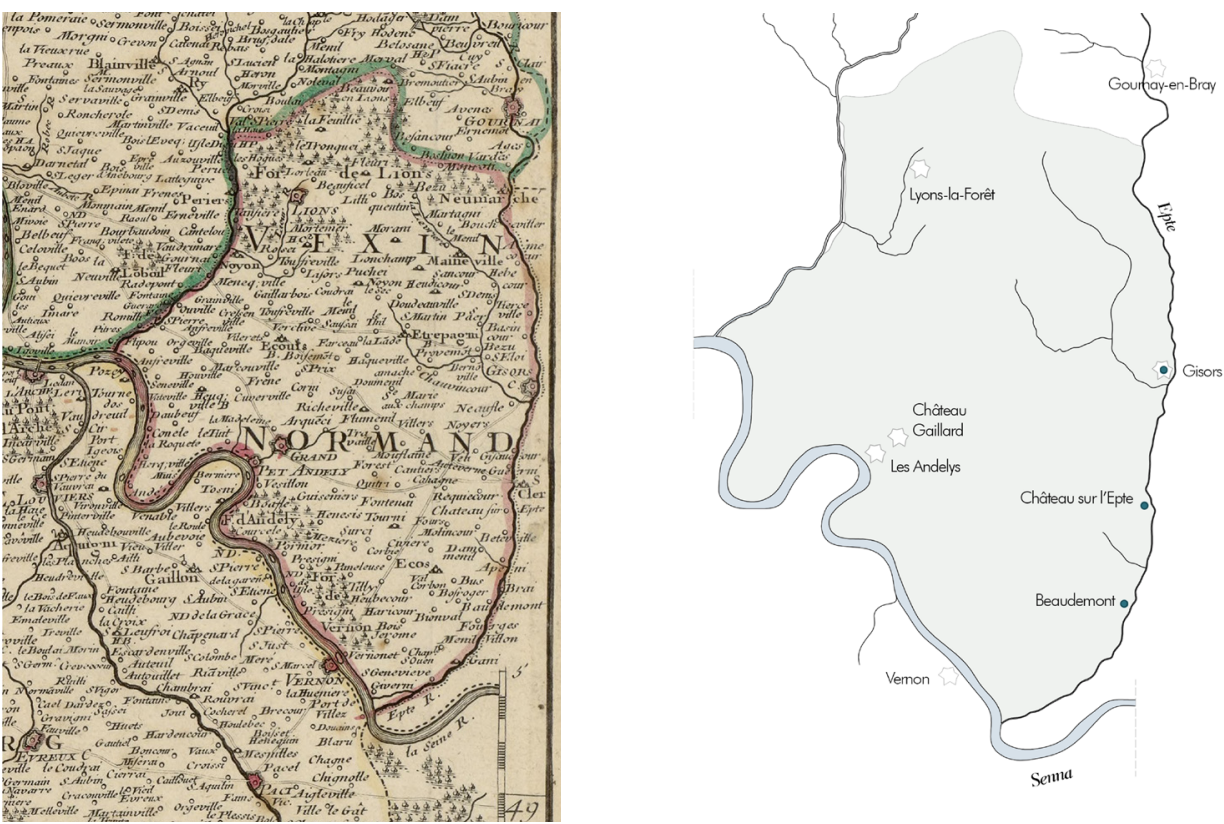

Le gerarchie urbane che segnano l'identità di un luogo sono presenti nel territorio e devono essere rintracciate anche in quelle città che, subendo profonde modifiche, hanno conservato un antico trascorso storico. Alla dimensione storica della città appartengono infatti architetture e matrici urbane specifiche, talmente caratterizzanti ed individuabili nel tessuto urbano, da permetterci ancora oggi di indentificare il centro storico rispetto ad una zona di più recente edificazione.

Nel territorio dell'Epte, gli elementi che determinano una prima fase storica, e che consideriamo gerarchie architettoniche, sono castelli e fortificazioni che segnano l'area in maniera inequivocabile tanto che, probabilmente, in un altro contesto, avrebbero continuato a svolgere un ruolo centrale nell'espansione urbana, divenendo essi stessi il centro storico delle relative città.

Ma ai fini della ricerca la questione si sposta sul poter leggere l'evoluzione urbana a larga scala di questo territorio, facendola emergere attraverso il disegno, seguendo sintatticamente le tracce dell'espansione dell'insediamento di frontiera.

I tre casi studio scelti nell'approfondimento di questa ricerca sono le città di Gisors, Château sur l'Epte e Beaudemont (fig. 7).

\section{L’analisi dei siti scelti per tappe evolutive}

Lo studio viene condotto per mezzo di una discretizzazione di informazioni dopo una precedente fase di lettura cartografica. Da questa operazione, illustrata attraverso tavole con schemi esemplificativi dei processi di trasformazione, è stato possibile mettere in luce le tappe principali caratterizzanti l'espansione urbana dei siti scelti.

I tre siti, Gisors, Château sur l'Epte e Beaudemont, sono stati analizzati evidenziando la loro espansione urbana sempre in rapporto con il fiume Epte, per tre periodi di riferimento: una prima fase databile XII secolo in cui vi era costruita solo la fortificazione, una seconda fase databile XV secolo che comprende lo sviluppo di un borgo abitato, ed infine un'ultima fase attribuibile al $\mathrm{XXI}$ secolo che mostra la conformazione attuale di queste città.

Questa esemplificazione schematica del rapporto tra città e territorio evidenzia caratteristiche similari nei fenomeni di sviluppo che colpiscono tutti e tre i casi studiati, sebbene ognuno di loro presenti all'interno differenze e peculiarità specifiche. 
La città di Gisors si mostra, fra le tre studiate, quella con l'estensione urbana più ampia. II primo nucleo urbano, il castello, si erge sull'altura creata dall'ansa dell'Epte che lo abbraccia per quasi due lati. Attorno al castello, nella seconda fase, il borgo abita la valle, occupando il territorio tra la fortificazione ed il limite del fiume. Nell'ultima fase infine, la grande espansione urbana della città di Gisors segue direttrici diverse: una fitta rete stradale attraversa la città condizionando lo sviluppo in direzione proprio di questi assi (fig. 8).

Il castello di Château sur l'Epte, nel secolo della sua edificazione, si colloca nella zona morfologicamente più rialzata rispetto al canale, con il borgo che successivamente abita l'intorno del castello stesso.

Nell'ultima fase di questa periodizzazione si nota però come il castello viene abbandonato dalla successiva urbanizzazione che, traslando a nord, si concentra lungo un sistema viario moderno in direzione nord/ovest-sud/est (fig. 9).
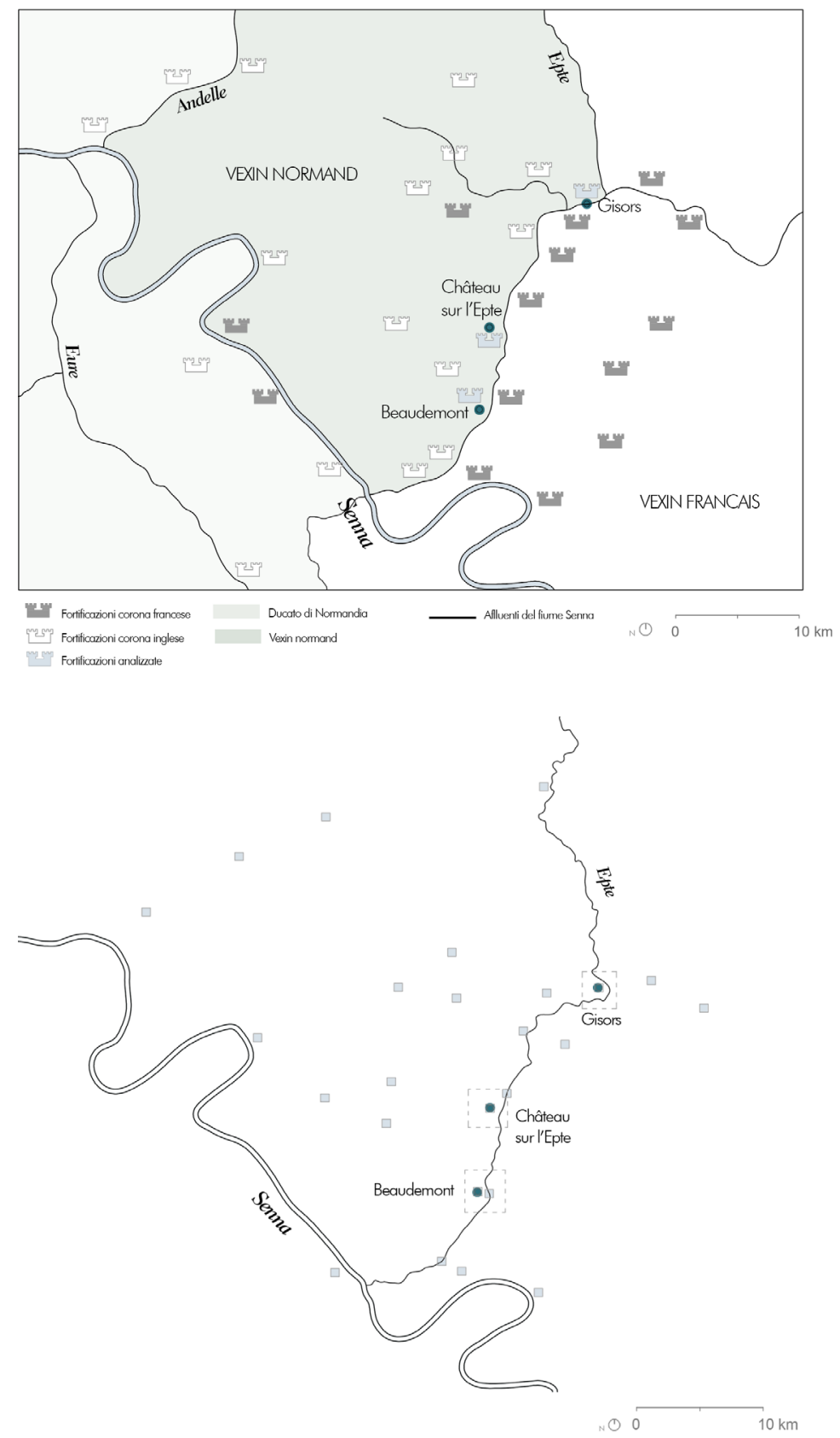
Fig. 8. Schemi esemplificativi di periodizzazione urbana per tappe della città di Gisors.

Fig. 9. Schemi esemplificativi di periodizzazione urbana per tappe della città di Château sur l'Epte.

Fig. 10. Schemi esemplificativi di periodizzazione urbana per tappe della
città di Beaudemont.
GISORS

Il castello

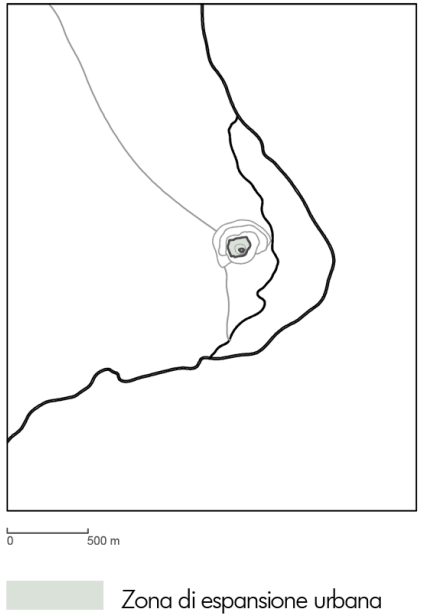

CHÂTEAU SUR L'EPTE

Il castello

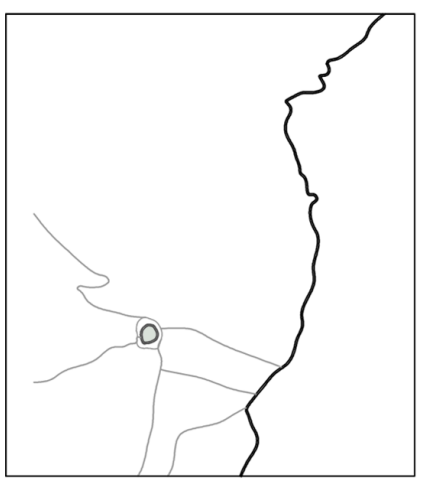

${ }_{500 \mathrm{~m}}$

Zona di espansione urbana

BEAUDEMONT

Il castello

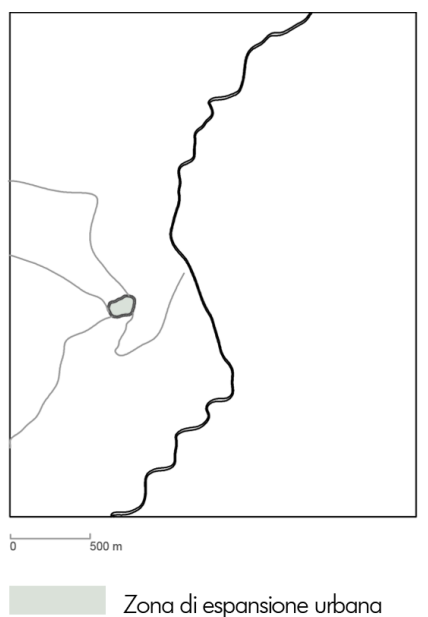

Il borgo
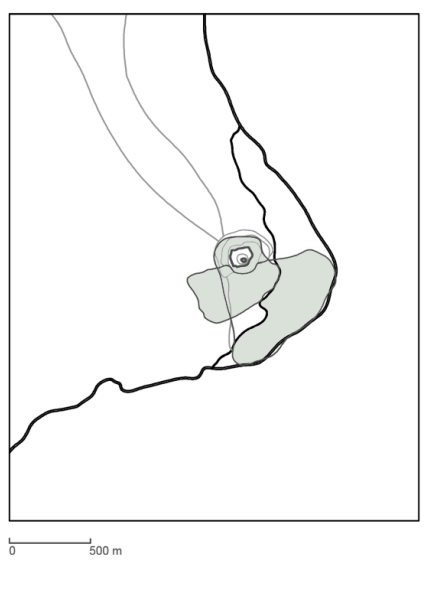

La città

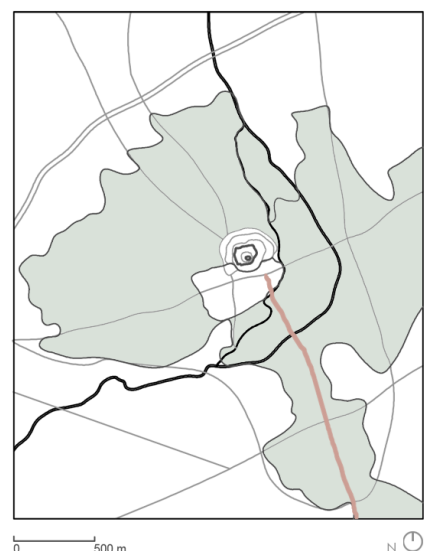

Sistema viario
Il borgo

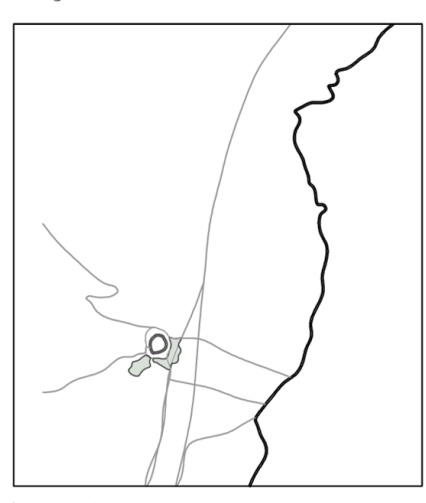

$500 \mathrm{~m}$

Epte
La città

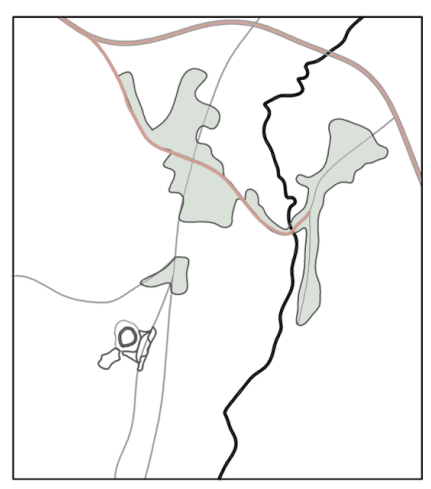

${ }_{500 \mathrm{~m}}$

${ }_{\mathrm{N}}(1)$ Assi direzionali
Il borgo

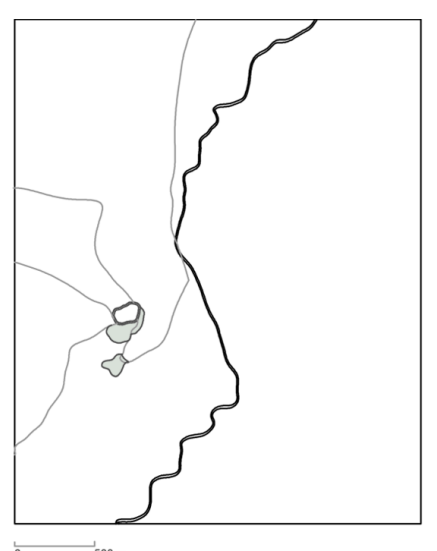

Epte
La città

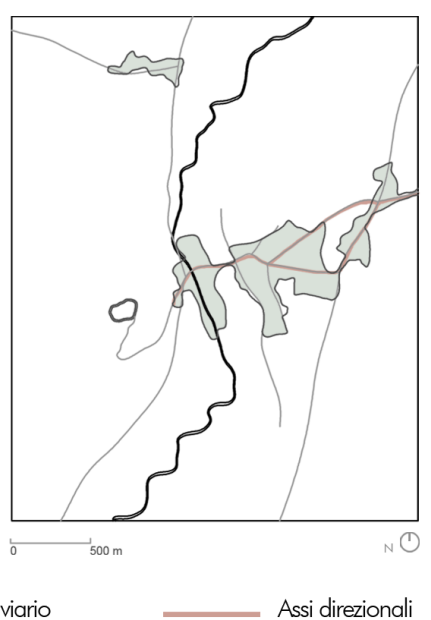


II terzo caso della cittadina di Beaudemont, la più geograficamente a sud delle tre, mostra nella prima fase la presenza della fortificazione poco distante dal canale e sempre in una posizione rialzata. Lo sviluppo successivo del borgo si concentra attorno alla fortificazione, per essere poi completamente dimenticato nell'ultima fase di sviluppo urbana, dove la città si estende al di là del fiume lungo il sistema viario, in direzione sud/ovest-nord/est (fig. I0). Lo studio del primo nucleo, la fortificazione, mostra come tutti i casi analizzati presentino le stesse caratteristiche ed i siti di fondazione rispondano alle stesse necessità politiche e strategiche, e quindi, territoriali, avendo così in comune le medesime caratteristiche morfologiche del luogo.

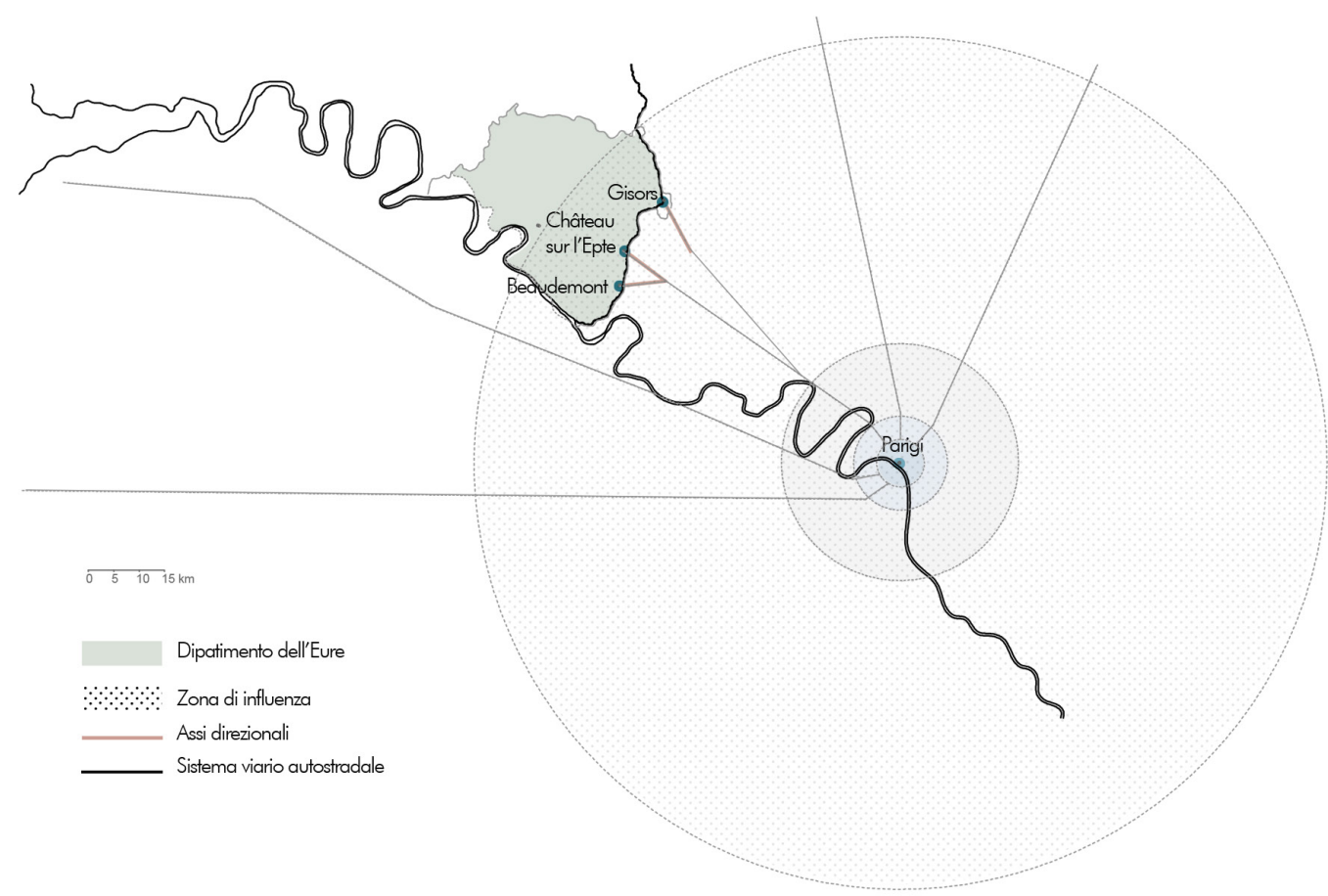

La seconda fase di studio del processo di inurbamento mette in luce come la città, in tutti i casi, venga fondata attorno alla costruzione esistente, ma questa volta rivolta verso valle. A conferma di ciò infatti sappiamo che il territorio viene riconquistato da Filippo Augusto nel XIII secolo, e così la frontiera di fortificazioni perde il suo ruolo difensivo, dando alle città la possibilità di fondarsi sulla valle dell'Epte. II disegno rintraccia le modalità di fondazione ed espansione delle città, ritrovando lo schema dell'inurbamento caratteristico della città medievale, confermato in tutti i casi esaminati.

La terza fase rintraccia nella cartografia il momento storico in cui si instaura in Francia una forte centralità politica nella città di Parigi e testimonia l'effetto centripeto che questo centro forte ha avuto nelle città intorno, che, invece, fino a quel momento avevano conservato una centralità ed una identità propria. Si evidenzia, con la lettura degli schemi della terza fase, in che modo l'urbanizzazione delle città si modifichi, orientandosi verso Parigi, esplicitando la differenza di relazione di forma tra quello che è un sistema a rete territoriale (la frontiera fortificata) ed un sistema centrale, offrendo una proposta di lettura sulle modalità in cui un territorio periurbano storico subisce l'influenza di un centro forte.

A testimonianza di ciò, la rete stradale viaria che collega radialmente Parigi alle città studiate coincide con gli assi direzionali di espansione urbana di quest'ultime. II confronto tra gli assi direzionali determinati dalla direzione delle strade di collegamento e l'ultima fase di urbanizzazione ( $X X \mid$ secolo) mette in luce un evidente parallelismo: le città si sviluppano infatti proprio lungo queste traiettorie, dimenticando la loro ex centralità data dall'originaria costruzione del castello (figg. I I, I2). 


\section{Conclusioni}

Lo studio morfologico dell'evoluzione urbana del territorio di frontiera dell'Epte evidenzia quelle gerarchie urbane caratterizzanti il processo di espansione delle città, affrontando la questione dell'azione centripeta delle capitali.

Focalizzare queste gerarchie, attraverso lo strumento del disegno e discretizzando le corrette informazioni, permette di evidenziare e rendere comprensibile le differenti fasi di urbanizzazione.

Alla luce di quando emerso, l'analisi vuole far riflettere sul quasi totale abbandono dei singoli centri storici minori in funzione di nuove città esterne, come Parigi, e di un nuovo sistema che dimentica l'identità del singolo e lo trasforma in qualcos'altro in un'ottica di globalizzazione e accentramento del potere.

Questo fenomeno, che sicuramente è giustificato in una Francia che si concentra nella città di Parigi e che una volta caduti i confini di frontiera interni ha potuto connetterli in un sistema centralizzato, rappresenta un dibattito aperto sui fenomeni di 'metropolizzazione' in piena espansione e sulle piccole città rurali in stato di abbandono progressivo.

L'analisi fatta si inserisce come risposta all'interrogativo posto in tesi sul come comprendere nella nostra contemporaneità la dimensione urbana, proponendo un contributo di lettura e di analisi.

Al lume delle considerazioni fatte ci chiediamo se, in un territorio così fortemente caratterizzato sia storicamente che geograficamente, il progressivo abbandono dei centri storici minori (detentori dell'identità caratterizzante il luogo) sia la posizione da mantenere per un vero sviluppo sostenibile, o altrimenti, quali siano le azioni da attuare per promuovere la rivitalizzazione del patrimonio attraverso l'azione progettuale?

Fig. I2. Schema di confronto tra urbanizzaziocittà analizzate (ultima città analizzate (ultima fase di periodizzazione) con gli assi direzionali derivanti dalle direzion delle strade di collegamento con Parigi.
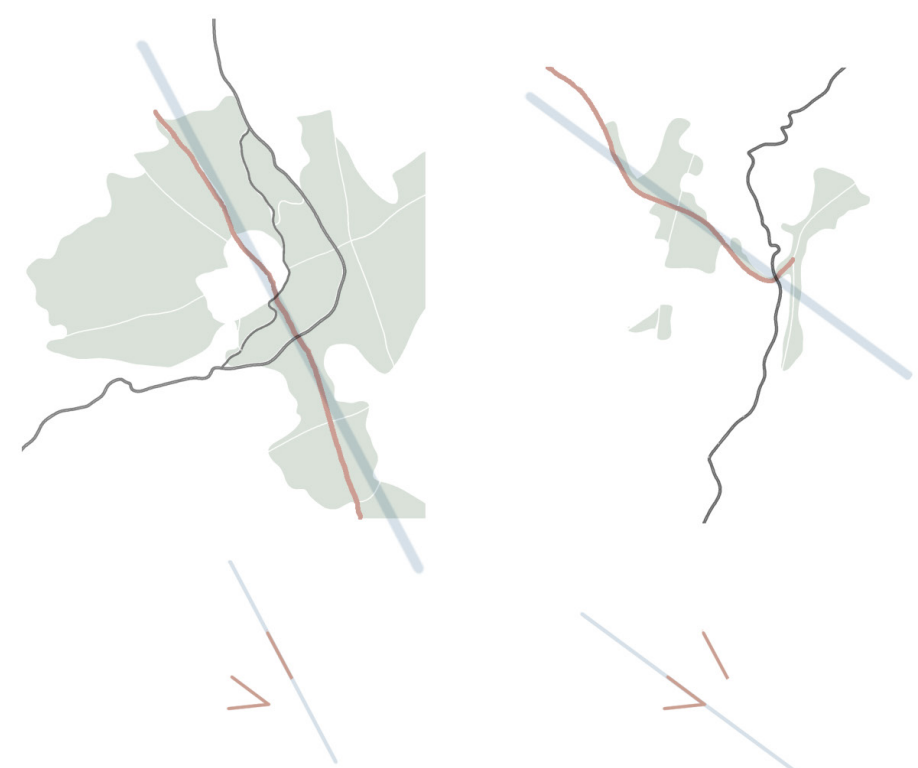

Zona di espansione urbana

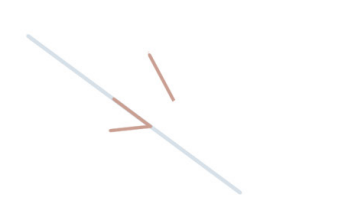

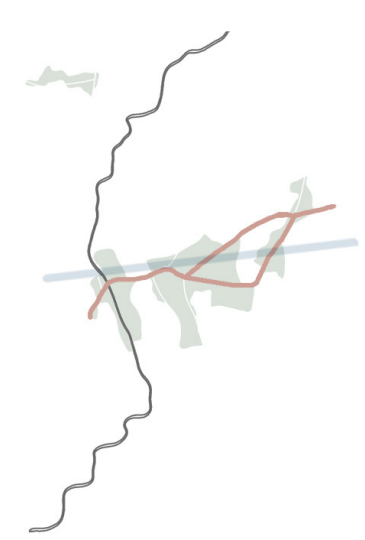

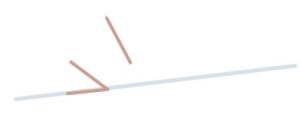

Nuova arteria viaria in direzione Parig

Note

[I] II seminario Villes et territoires entre mémoire et actualité è un corso semestrale svolto presso École Nationale Supérieure de Paris Val de Seine, dall'équipe di professori formata da Marc Dilet, Laurence Feveile, Léa Mosconi, Philippe Simon e Mathieu-Hô Simonpoli. Si iscrive all'interno del $4^{\circ}$ anno del corso di laurea in Architettura come corso di preparazione allo sviluppo della tesi magistrale dell'anno successivo. 


\section{Riferimenti bibliografici}

Bini Marco (2005). Il castello di Gisors. Resoconto della campagna di rilievo per una ricerca tipologica e funzionale. Firenze: Alinea Editrice.

Choux Jacques (1978). Bulletin Monumental. Lorraine: Meurthe-et-Moselle, Meuse, Moselle, Vosges. Dictionnaire des châteaux de France, tome 137, n. 2, pp.196- 197.

De Dion Adolphe (1873). Bibliothèque de l'école des chartes. Note sur les progrès de l'architecture militaire sous le règne de Philippe-Auguste, tome 34. p. 617. Paris: Librairie d'Alphonse Picard.

Erlande-Brandenburg Alain, Jacques Choux (1979). Lorraine: Meurthe-et-Moselle, Meuse, Moselle, Vosges. Dictionnaire des châteaux de France. Bulletin Monumental, tome 137, n², année 1979. pp. 196-197.

Finò José Federico (1977). Forteresses de la France médiévale. Construction - Attaque - Dèfense. Paris: Éditions A. et J. Picard

Fournier Gabriel (1979). Le château dans la France médiévale. In Bulletin Monumental, tome I37, n. 2, pp. 183 - 185.

Fruit Jean-Pierre (1974). Vexin normand ou vexin Parisien? Contribution à l'étude géographique de l'espace rural. Mont-SaintAignan: Presses universitaires de Rouen et du Havre.

Héliot Pierre (1965). Les châteaux-forts en France du Xe au Xlle siècle à la lumière de travaux récents. In Journal des savants, n. 2, pp. 483-5। 4.

Le Corbusier (1946). Manière de penser l'urbanisme. Paris: Gonthier Editeur (2d ed), 1966.

Lepeuple Bruno (2008). Deux contre-châteaux d'Henri ler Beauclerc en I I | 8- I | | 9: approche historique et topographique In Roch Jean-Louis, Lepeuple Bruno, Lalou. Des chateaux et des sources. Mont-Saint-Aignan: Presses universitaires de Rouen et du Havre, pp. |87-201.

Lucan Jacques (2012). Où va la ville aujourd'hui?: Formes urbaines et mixités. Paris:Villette Editeur.

Mesqui Jean, Toussaint Patrick (1990). Le château de Gisors aux Xlle et XIlle siècles. In Archéologie médiévale, tome 20, pp. 253-317.

Pepin Eugene (1963). Gisors et la Vallee de l'Epte. Paris: Henri Laurens Editeur.

Seydoux Philippe (1979). Forteresses médiévales du nord de la France. In Revue du Nord, janvier-mars, tome 64, n. 252, pp. $217-218$

Sources matériaux cartographiques: gallica.bnf.fr / Bibliothèque Nationale de France.

Viollet-le-Duc Eugène ( I 854). Dictionnaire raisonné de l'architecture française du Xle au XVle siècle. Paris: B. Bance Editeur.Vol. I

Autore

Marta Zerbini, Università degli Studi di Firenze, marta.zerbini@unifi.it

Per citare questo capitolo: Zerbini Marta (2020). L'impronta della dinamica storica dell'insediamento di frontiera: l'Epte in Normandia, Francia/ The traces of historical dynamics in a border settlement: the study of Epte River in Normandy, France. In Arena A., Arena M., Brandolino R.G. Colistra D., Ginex G., Mediati D., Nucifora S., Raffa P. (a cura di). Connettere. Un disegno per annodare e tessere. Atti del $42^{\circ}$ Convegno Internazionale dei Docenti delle Discipline della Rappresentazione/Connecting. Drawing for weaving relationships. Proceedings of the 42th International Conference of Representation Disciplines Teachers. Milano: FrancoAngeli, pp. | 466-| 485. 


\title{
The Traces of Historical Dynamics in a Border Settlement: the Study of Epte River in Normandy, France
}

\author{
Marta Zerbini
}

Abstract

In this project, we propose the analysis and the reading of a territory and the cities that inhabit it, working to identify procedures and types of intervention that throughout centuries have defined its actual shape.

Drawing becomes a tool to trace these differences that are witnesses of the urban transformation of the territory, investigating its nature and questioning its shape.

With this project, we focus on the study of the fortified border along the river Epte, in Normandy: it's a territorial system that was born as a series of fortifications, then developed in villages, and finally transformed under the influence of a strong city.

The study focuses on the evolution over time of the urbanization process, involving three main elements: castles, villages and new cities.

This reading proposal is focused on the urban transformation of a territory where an ancient historical identity and an influence of an outside strong center coexist.

The contribution shows as Drawing can read and understand phenomena of urban development, opening the way to wider contemporary reflections on how to design within these territories and how to act to calm or rather amplify certain developments.

Keywords

fortified border, river Epte, Normandy, castles, urban expansion phenomena.

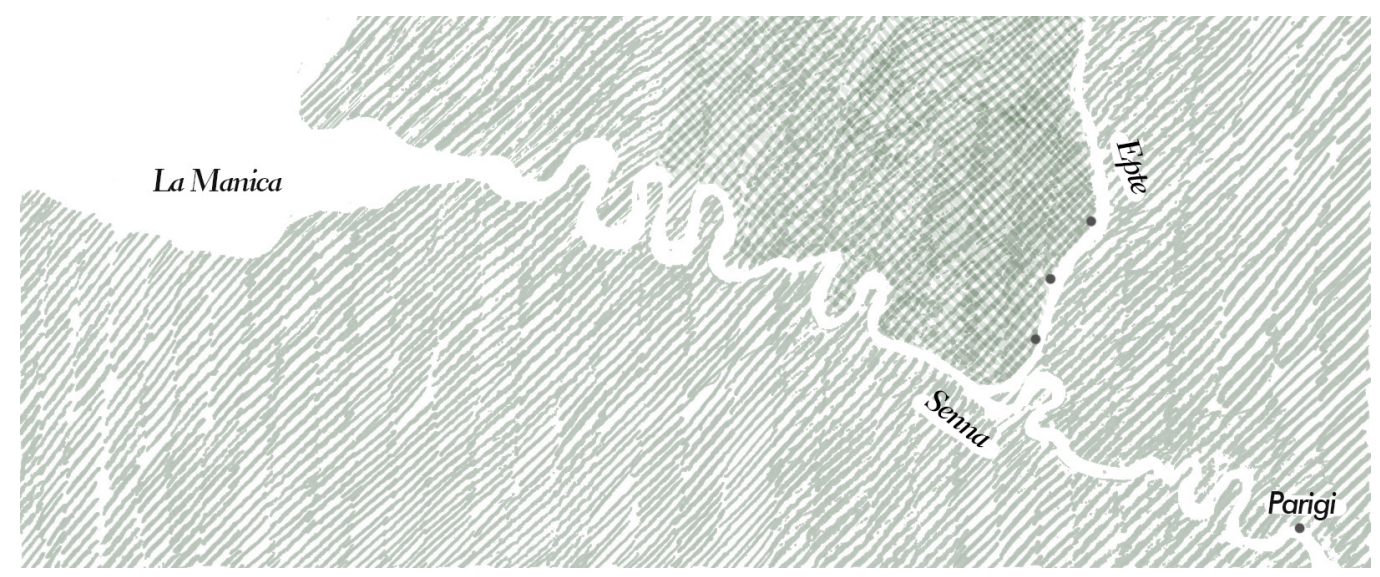




\section{Introduction}

The study is part of an open research within the seminar Ville et territories entre memoire et actualité held at the Ecole Nationale Superiéure d'Architecture in Paris Val De Seine [I] . The name of the seminar Cities and territories between memory and actuality reveals the issue of the temporal evolution of a place, referring also to its historical transformation.

The central theme is the city, analyzed at different scales and in different eras, according to its development processes.

Among the phenomena of international 'metropolization' in full expansion and the small still rural cities in a state of progressive emptying, we wonder how to understand in our contemporaneity the urban dimension.

How to design within these territories and how to act to calm or rather amplify certain developments?

There is a current debate about the transformation of historical realities (i.e. villages, cities, and territories) under the strong influence of metropolitan expansions.

It represents an interesting interdisciplinary topic from either the drawing and architectural perspectives. If we consider the city as the result of the time it has lived, of the men who built it and of the cultures that inhabited it, it is precisely in its stratification, expansion, or elision that we can trace the lines of its past and its history.

The traces of the actions that have shaped the cities and their territories, starting from those of foundation up to those that have determined the actual conformation, are identifiable through urban and geometric matrices: reading them in time, sometimes confirmed or sometimes betrayed, they mark the way to understanding the mutation of the cities or territories.

Drawing, thanks to its critical and analytical potential, is the tool that allows us to trace these inconsistencies witnesses of the territorial transformation, and we present it here applied to a specific case study: the fortified frontier of Epte river.

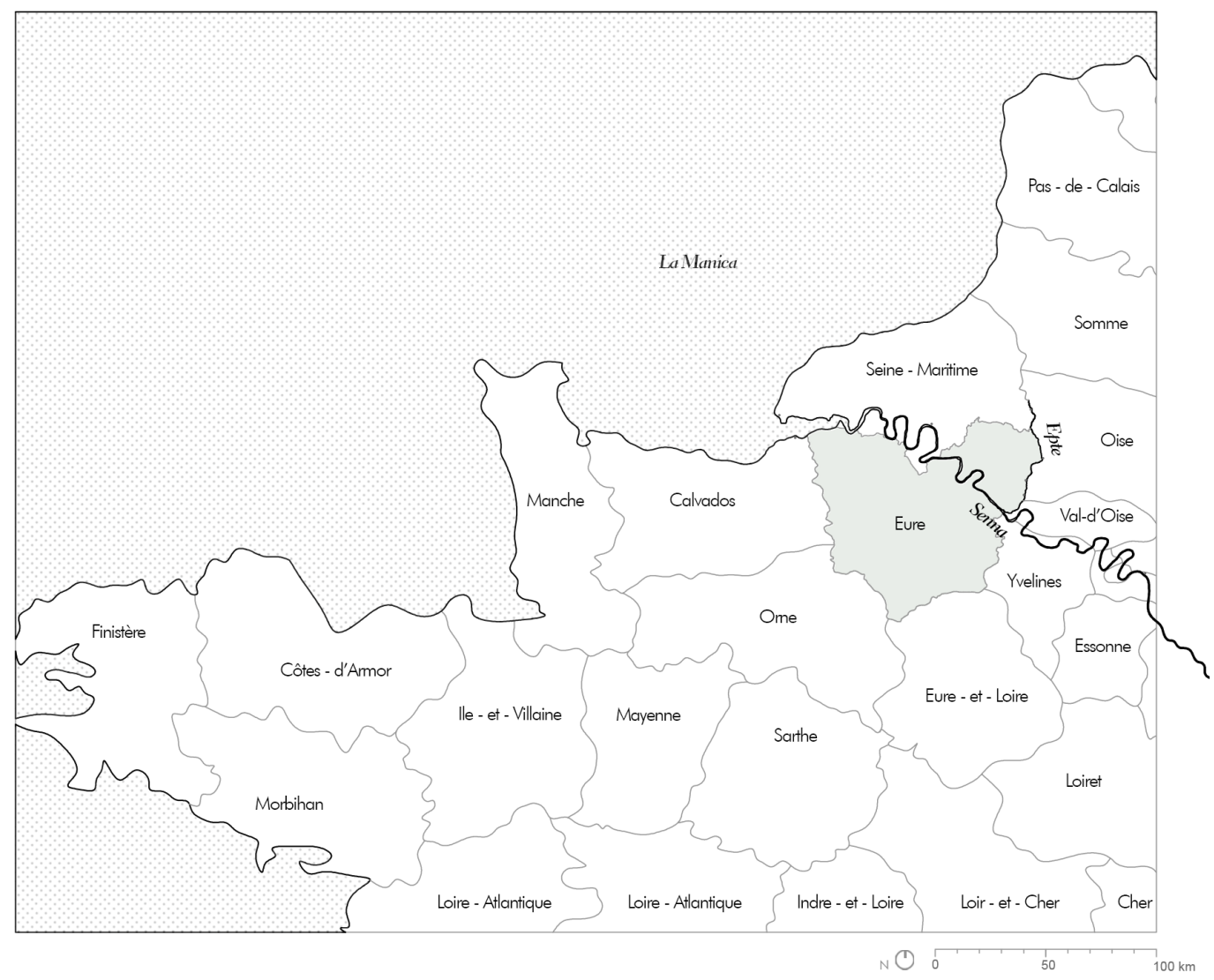


In order to narrow down the analysis, we identify three main evolutionary phases in this territorial system: it was born as fortification, it was developed as a village, and finally it was transformed under the influence of a strong city. The research finally focuses on the process of urbanization that links these three phases in a relationship between a territorial network system and a central system.

Fig. 2. The territorial classification of the Eure departement in relation to River Epte and the main cities of the territory.

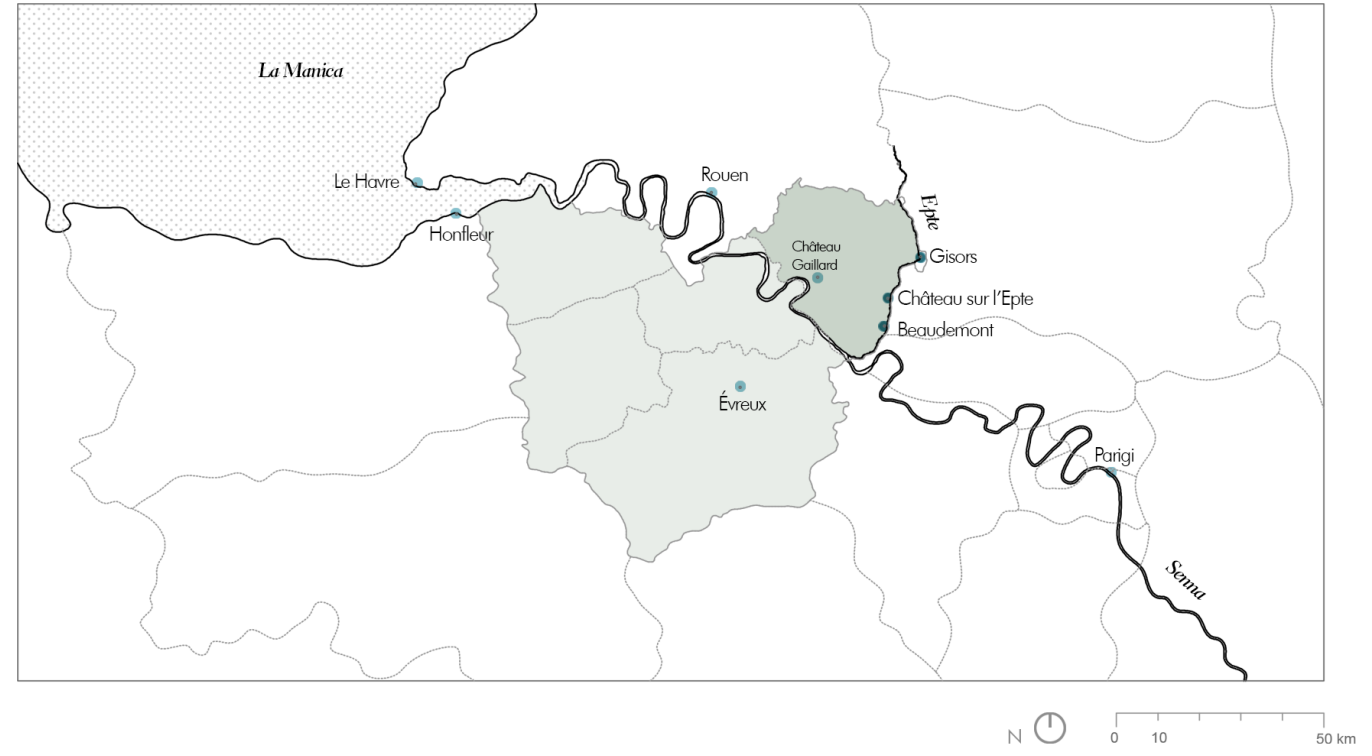

\section{The fortified border of Epte: geographical and historical context}

The first part of the research is focused on its geographical and historical context. The River Epte is a tributary of the River Seine that flows north-west of Paris. It rises in the municipality of Compainville (department of Seine-Maritime in Normandy) and continues southwards. Crossing cities like Gisors, Saint Clair sur Epte, Château sur Epte, Gasny and Giverny, the river Epte marks the border between Normandy to the west and Hauts-de-France and I'lle de France to the east [Bini 2005, pp 6-23] (fig.l).

The Epte marks significantly marks the surrounding territory, and how its geographical shape determines the transformation of the landscape and its strategic value (fig. 2).

The importance of the tributary Epte in history goes back to the tenth century, when it was a natural limes between the territory inhabited by Normans and that populated by French. Its strategic position has made that borders the more disputed in the history of the eleventh century between the English crown and the French one (figs. 3-5).

Already in the historical geography of the tenth century, in fact, this river marked the natural boundary between the Norman Vexin and the French Vexin and for the length of its course was punctually studded with minor fortifications belonging to Norman Counts.

Since the Norman Counts had an ambiguous political loyalty towards the two crowns, the English and the French ones, King of England Henry I decided to build there a series of fortresses and castles under his direct control. He allowed Norman people to continue to live in its territory in exchange for manpower and building materials [Bini 2005, pp 57-64]. Through this construction operation under the English crown, the tributary Epte becomes a real fortified frontier separating the Duchy of Normandy from the rest of the French domination territory. 
To prove the importance of this border in the past, still today the river continues to fulfill the function of limit in the new departmental borders of the French territory. The castles, that functioned as defensive elements on the territory and that have populated the course of the river, are nowadays still largely traceable in the medieval villages. Villages have in fact inhabited those ancient fortifications, inheriting also their names (fig. 6).

In a temporal and historical succession, the same villages have expanded themselves around their castles, till to change their urban orientation, turned under the centripetal force of Paris metropolis that radially attracts to itself the cities around.

Fig. 3. Guillaume Delisle, Carte de Normandie, 1716, Bibliothèque Nationale de France, département Cartes et plans, GE DD2987 (448 B): <https:// gallica.bnf.fr/ark:/ 12148 btvlb53052675v>.

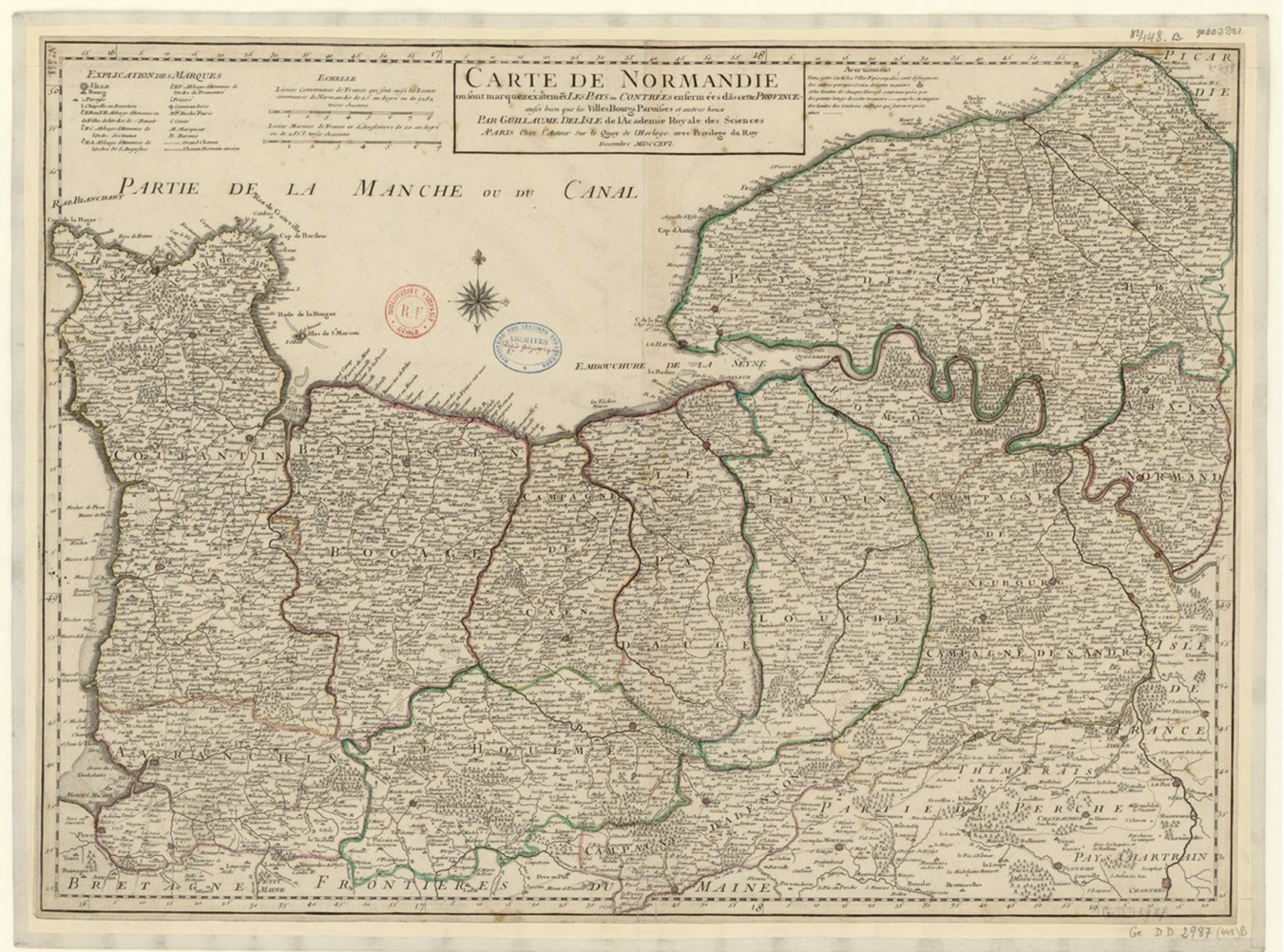

Source gallica.bnf.fr / Bibliothèque nationale de France

\section{Fortifications and castle-cities on the border settlement of Epte}

After the description of logical process that links the steps of the urban transformation of the Norman fortified border this chapter is focused on the analyses of case studies.

The case studies consist of individual urban centers which emerge along the River and which share the same territorial characteristics. All the fortifications analyzed arise on the same type of territorial morphology: with fortifications upstream and urban development downstream, their construction is datable in the same historical periods and are all built by the same local labor, sharing history and culture.

In this phase we discover analogies and rules between each case study, allowing us to better understand this territorial border both as a barrier and as a united front.

This comparison shows how it has changed in history and how these changes have left physical traces in the cities of this territory.

The urban hierarchies determine the identity of a place. They can be traced in historical cities, even if they have undergone profound changes. 
Fig. 4. Guillaume Delisle, Carte de Normandie, 1716, dettaglio: detail of Vexin Normanno, Bibliothèque Nationale de France, département Cartes et plans, GE DD2987 (448 B): $<$ https $/$ gallo blvib5052675v.

Fig. 5. Re-elaboration of historical cartography representing the region of the Norman region (the Norman Vexin).
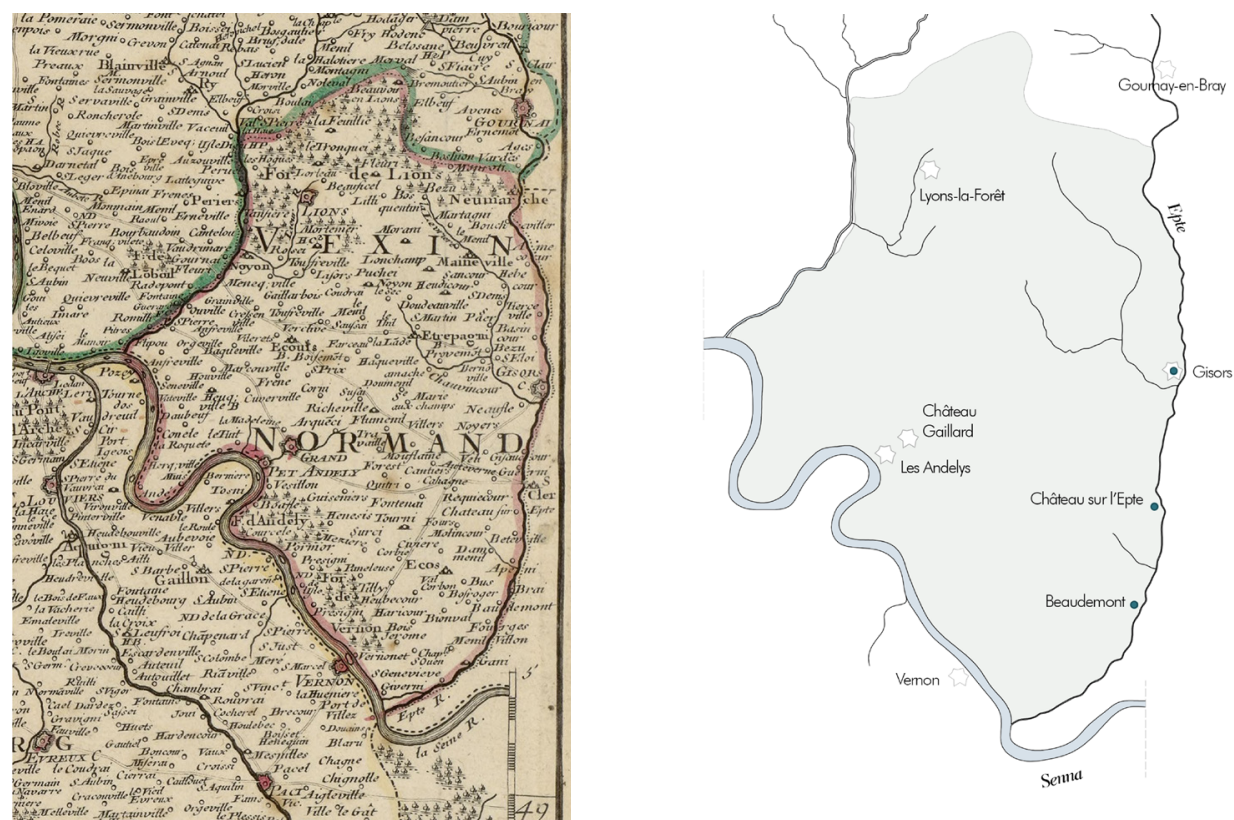

In fact, the historical dimension of a city is characterized by specific architectures and urban matrix that can be found in urban tissue identifying also the city's historical center.

In the territory we study, the architectural elements of a first historical phase are composed by castles and fortifications. Their presence is strong enough to mark the land in an indisputable way. Probably, in another context, they would have continued playing a central role in urban development, representing their cities' historical centers.

But to develop our research the paper focuses on the possibility to read the urban transformation of this territory, through urban drawing, following the traces of historical dynamics of this border settlement.

The three case studies analyzed in this research are the cities of Gisors, Château Sur l'Epte, and Beaudemont (fig. 7).

\section{The study of case studies by evolutionary stages}

The study discretizes a series of information after an earlier phase of cartographic reading. The output of this phase is a series of illustrated tables with diagrams explaining the cities' transformation processes, where it's possible to highlight the main stages characterizing the urban expansion of the sites chosen.

We analyze the urban expansion of the three sites, Gisors, Château sur l'Epte, according to three reference periods: a XII century phase in which there was built only the fortification, a fifteenth century phase that includes the development of an inhabited village, and finally a twenty-first century phase that shows the current shape of these cities.

This schematic example of the relationship between city and territory highlights similar characteristics in the development phenomena that affect all three cases studied, even though with differences and specific peculiarities.

The city of Gisors shows itself, among the three studied, the one with the largest urban extension. The first urban nucleus, the castle, rises on the high ground created by river Epte's course that embraces it for almost two sides. During the second phase, the village inhabits the valley around the castle, occupying the territory between the fortification and the limit of the river. 
In the last phase, finally, the great urban expansion of the city follows different directions: a dense road network crosses the city conditioning the urban development in those directions (fig. 8).

The castle of Château sur l'Epte is in the morphologically more elevated area in the century of its construction, with the village that later inhabits the castle itself.

In the last phase of this periodization, however, we notice how the castle and the village are abandoned by the later urbanization which, moving north, develops itself along a modern road system in a north/west - south/east direction (fig. 9).

The third case of the city of Beaudemont, the more geographically south of the three, shows in the first phase the presence of the fortification not far from the river Epte and always in a raised position.

Fig. 6. Re-elaboration of the historical cartography representing the fortifications in the frontier Epte and differentiated by crown of belonging.

Fig. 7. Exemplification of the territory through the hydrography with castles attested in || 50 .

Highlighted among these Highlighted among these the three selected case
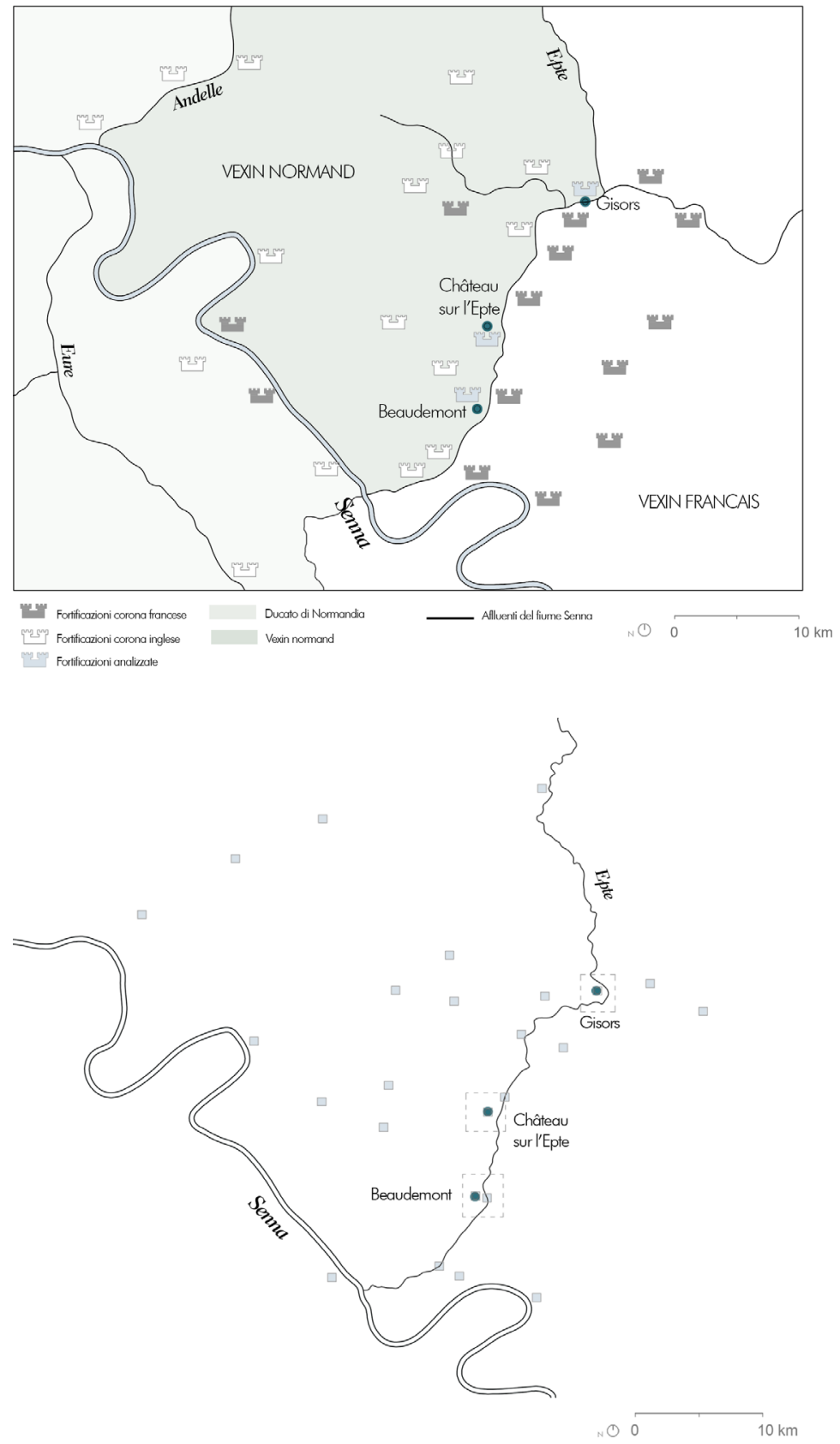


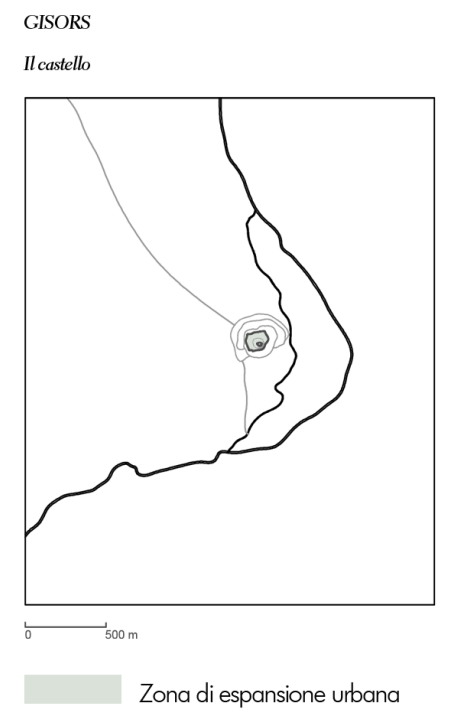

CHÂTEAU SUR L'EPTE

Il castello

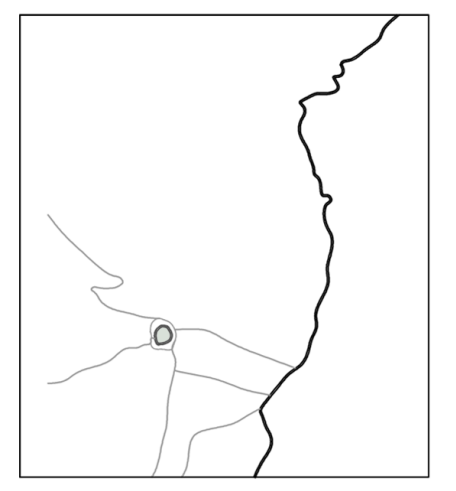

$\checkmark 500 \mathrm{~m}$

Zona di espansione urbana

on schemes in

Château sur l'Epte.

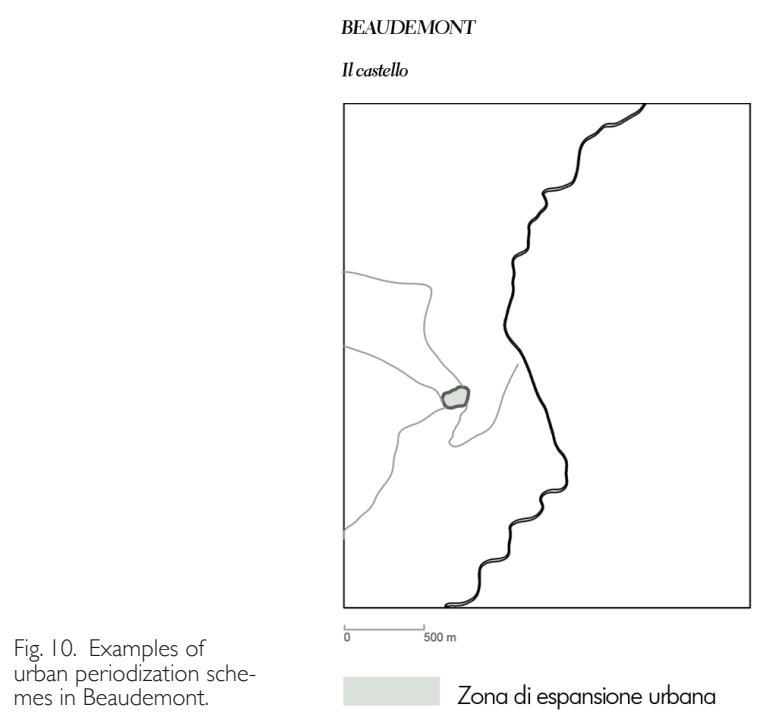

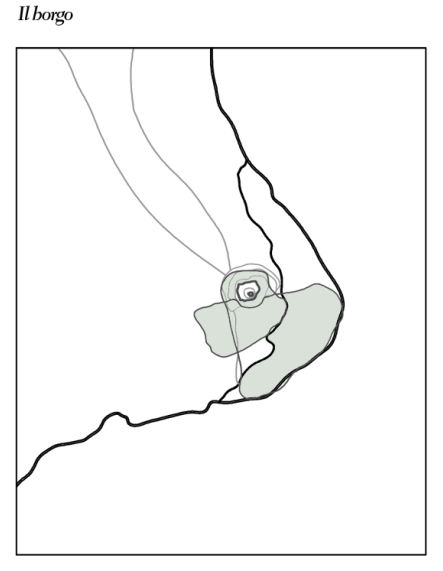
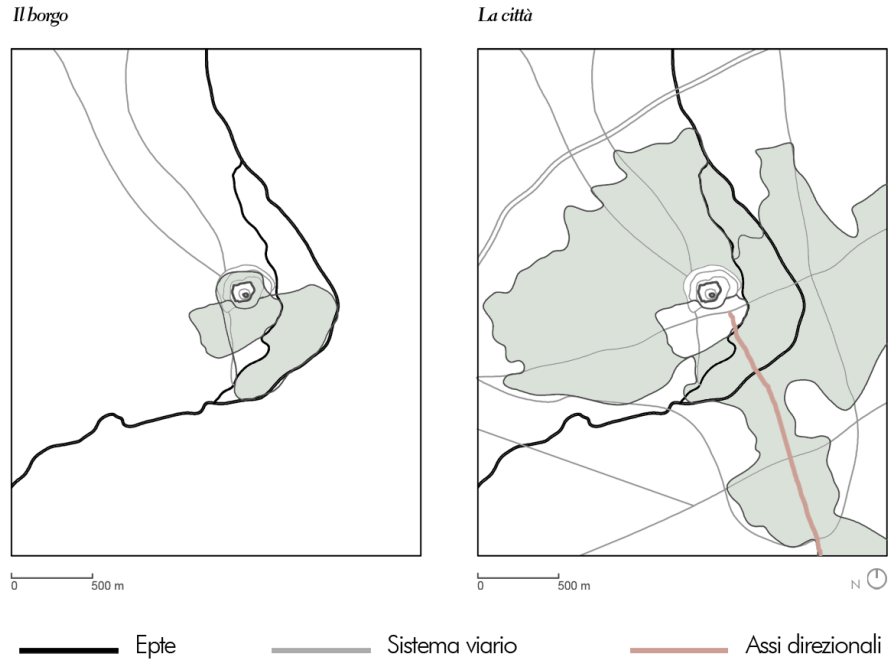

Il borgo

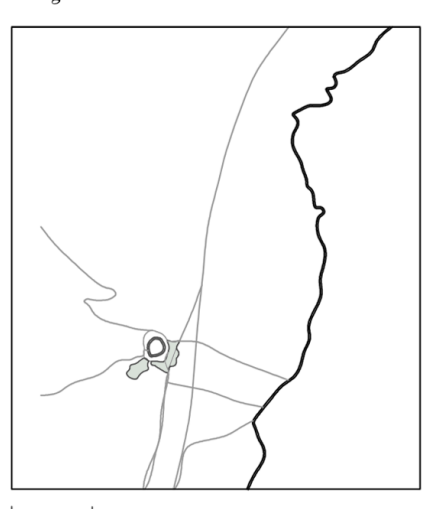

La cittò

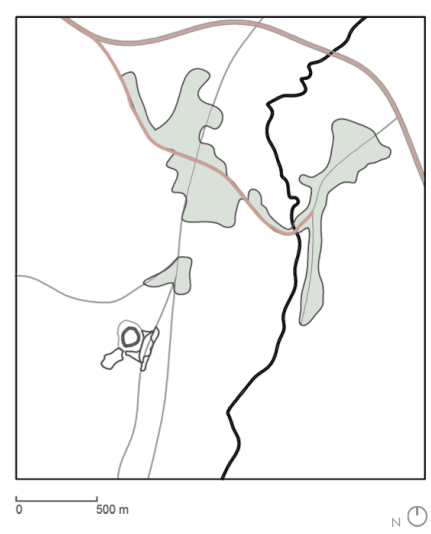

Assi direzionali

Il borgo

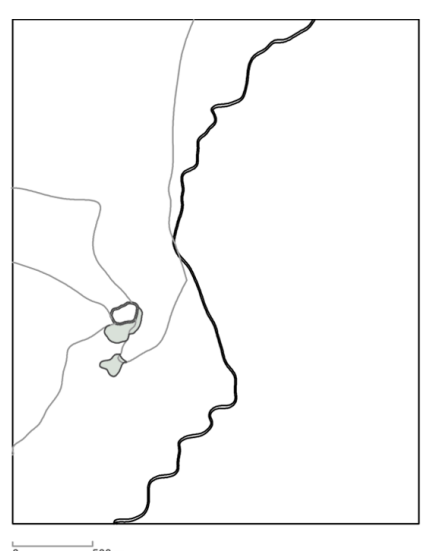

Epte

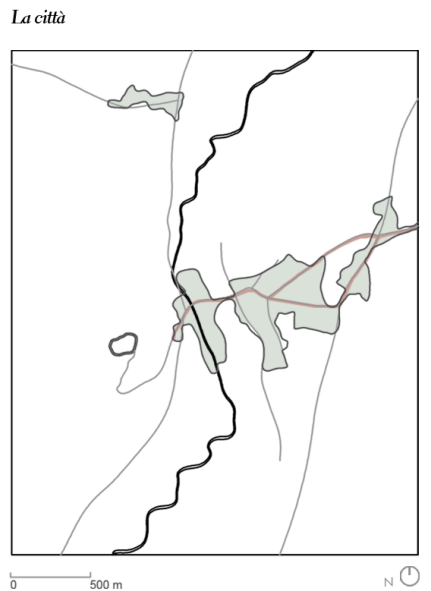

Assi direzionali 
The following extension of the village is concentrated around the fortification, to be then completely forgotten in the last phase of urban development, where the city extends beyond the river along the road system, in direction South/West-North/East (fig. I0).

The study of the first nucleus, the fortification, shows how all the cases analyzed present the same characteristics and the foundation sites respond to the same political and strategic needs, and therefore, territorial, thus having in common the same morphological characteristics of the place.

The second phase of study of the urbanization process highlights how the city, in all cases, is founded around the existing building, facing the valley.

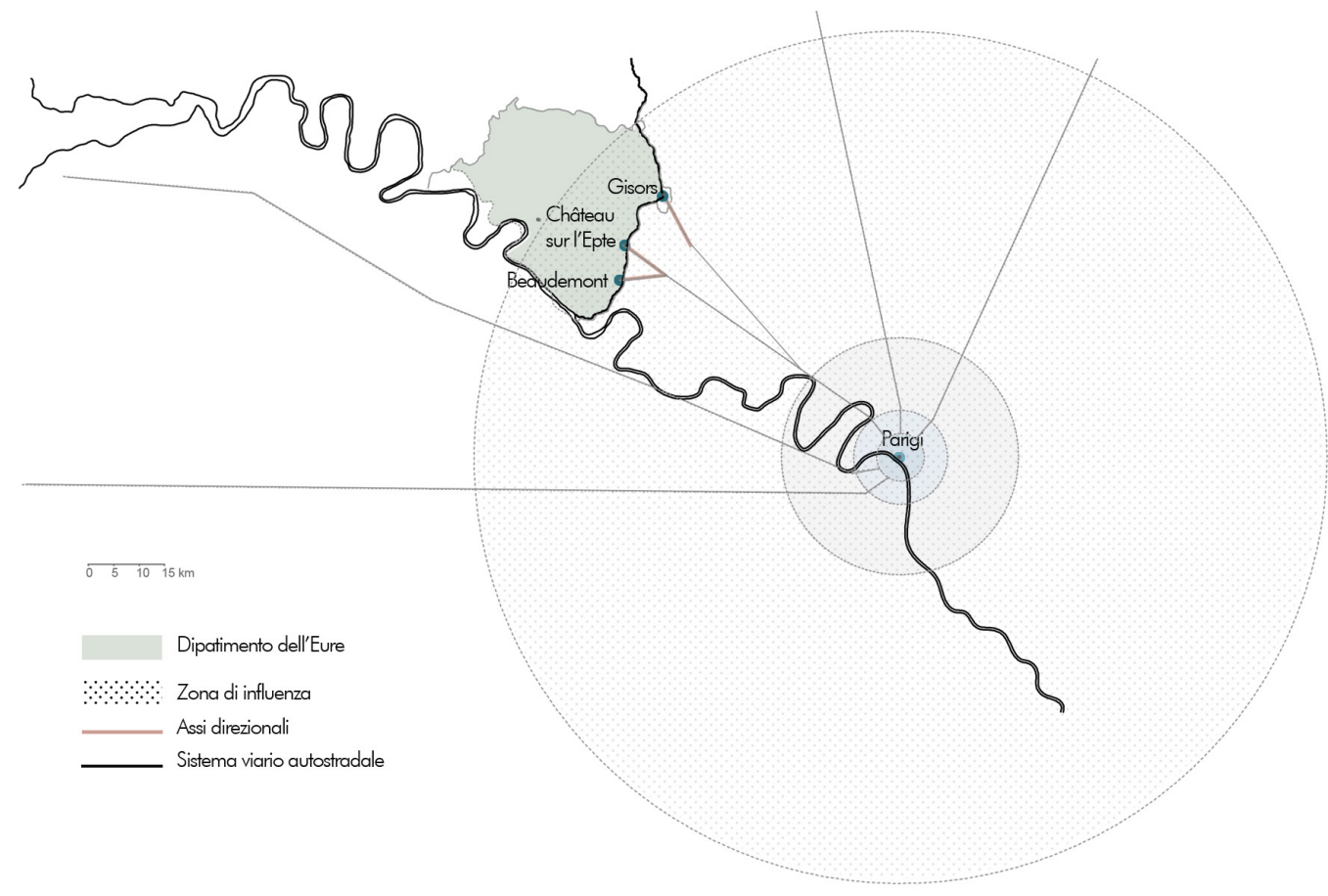

The territory is reconquered by Philip Augustus in the XIII century, and so the fortified border loses its defensive role, giving the cities the possibility to found themselves in the valley. The tool of drawing allows us to identify city foundation and expansion modalities, finding out the scheme of urbanization of medieval city.

The third phase captures in the cartography the historical moment in which a strong political centrality is established in France in the city of Paris. It shows the centripetal effect of a strong center as Paris into the cities around obscuring their centrality and identity.

Reading the diagrams of the third phase we observe how the expansion of the cities is oriented towards Paris. This explains the difference of relationship between a territorial network system (the fortified border) and a central system. It shows also how a peri-urban historical territory is influenced by a strong center.

The road network that radially connects Paris to the cities studied coincides with the urban expansion axes of the latter. The comparison between the directional axes determined by the direction of the connecting roads and the last phase of urbanization ( $X X \mid$ century) shows a clear parallelism: cities develop along these trajectories, forgetting their former centrality given by the original construction of the castle (figs. I I, I2). 


\section{Conclusions}

The morphological study of the urban evolution of the frontier territory of Epte identifies the main phases of the process of expansion of the cities, highlighting the centripetal action of the capitals.

The tool of Drawing allows us to highlight and make understandable the different phases of urbanization. The analysis aims to highlight the almost total abandonment of the individual smaller historical centers in function of new external cities, like Paris, and a new system that forgets the identity of the individual and turns it into something else in a perspective of globalization and centralization of power.

This phenomenon, which is justified in a France concentrated in the city of Paris and without internal borders, represents an open debate on the tipic of metropolitan expansion and small rural cities in a state of progressive abandonment.

The analysis answers to the question: how to understand in our contemporaneity the urban dimension?

We wonder whether, in a territory so strongly characterized both historically and geographically, the progressive abandonment of the smaller historical centers (holders of the identity characterizing the place) is the right attitude for a possible urban sustainable development, or otherwise, what actions should be implemented to promote the revitalization of the heritage through the project?

Fig. 12. Scheme of comparison between the urbanization of twenty-first century cities (third phase of periodization) with the directiona axes deriving from the directions of the roads
connecting with Paris.
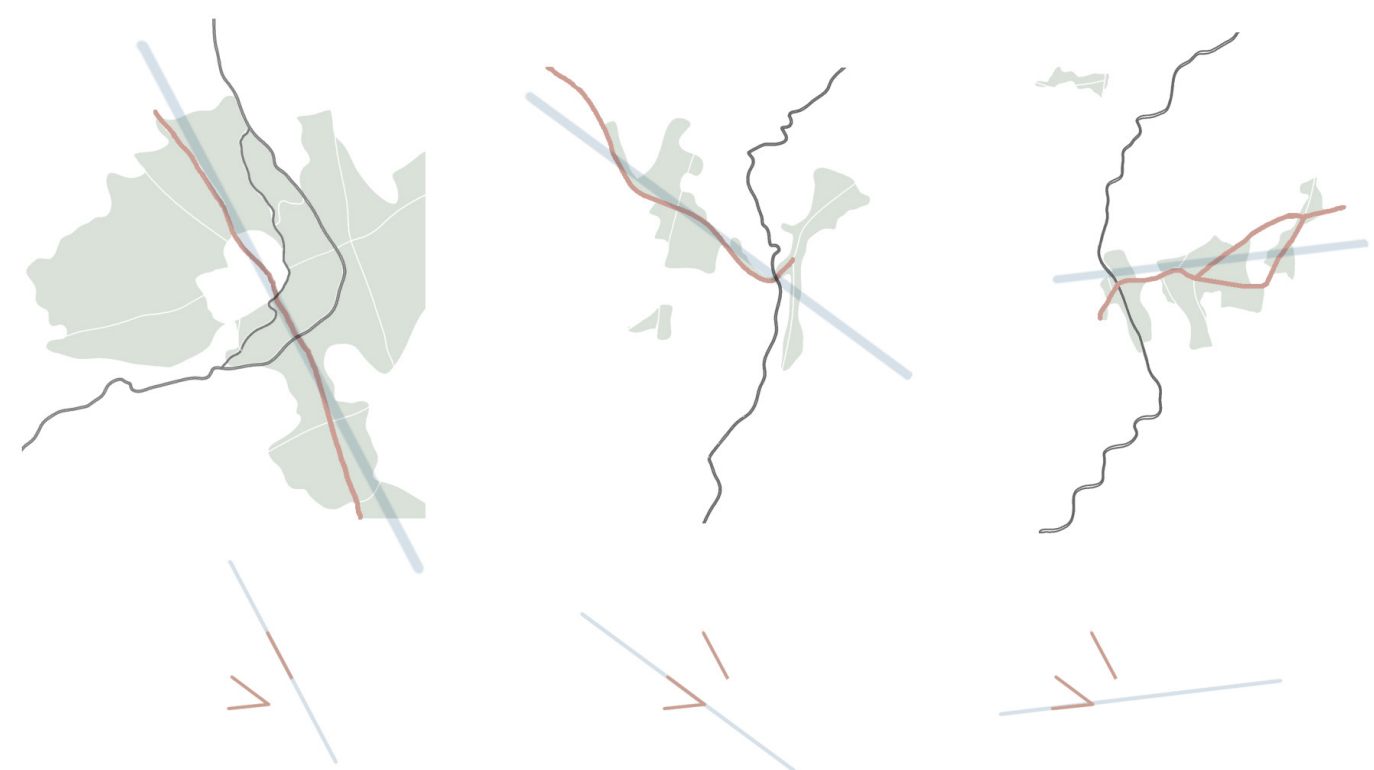

Zona di espansione urbana
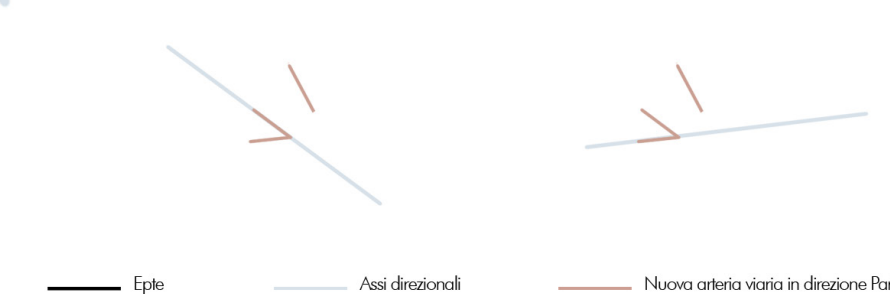

Nuova arteria viaria in direzione Parigi

\section{Notes}

[I] The seminar Villes et Territoires entre mémoire et actualité is a semester course held at the Ecole Nationale Superiéure de Paris Val de Seine, by the team of professors formed by Marc Dilet, Laurence Feveile, Léa Mosconi, Philippe Simon, and Mathieu-Simonhô. It's planned within the $4^{\circ}$ year of architecture as a preparation course for the development of the master thesis of the following year. 


\section{References}

Bini Marco (2005). Il castello di Gisors. Resoconto della campagna di rilievo per una ricerca tipologica e funzionale. Firenze: Alinea Editrice.

Choux Jacques (1978). Bulletin Monumental. Lorraine: Meurthe-et-Moselle, Meuse, Moselle, Vosges. Dictionnaire des châteaux de France, tome 137, n. 2, pp.196- 197.

De Dion Adolphe (1873). Bibliothèque de l'école des chartes. Note sur les progrès de l'architecture militaire sous le règne de Philippe-Auguste, tome 34. p. 617. Paris: Librairie d'Alphonse Picard.

Erlande-Brandenburg Alain, Jacques Choux (1979). Lorraine: Meurthe-et-Moselle, Meuse, Moselle, Vosges. Dictionnaire des châteaux de France. Bulletin Monumental, tome 137, n², année 1979. pp. 196-197.

Finò José Federico (1977). Forteresses de la France médiévale. Construction - Attaque - Dèfense. Paris: Éditions A. et J. Picard

Fournier Gabriel (1979). Le château dans la France médiévale. In Bulletin Monumental, tome I37, n. 2, pp. I83- 185.

Fruit Jean-Pierre (1974). Vexin normand ou vexin Parisien? Contribution à l'étude géographique de l'espace rural. Mont-SaintAignan: Presses universitaires de Rouen et du Havre.

Héliot Pierre (1965). Les châteaux-forts en France du Xe au Xlle siècle à la lumière de travaux récents. In Journal des savants, n. 2, pp. 483-5। 4.

Le Corbusier (1946). Manière de penser l'urbanisme. Paris: Gonthier Editeur (2d ed), 1966.

Lepeuple Bruno (2008). Deux contre-châteaux d'Henri ler Beauclerc en I I | 8- I | | 9: approche historique et topographique In Roch Jean-Louis, Lepeuple Bruno, Lalou. Des chateaux et des sources. Mont-Saint-Aignan: Presses universitaires de Rouen et du Havre, pp. |87-201.

Lucan Jacques (2012). Où va la ville aujourd'hui?: Formes urbaines et mixités. Paris:Villette Editeur.

Mesqui Jean, Toussaint Patrick (1990). Le château de Gisors aux Xlle et XIlle siècles. In Archéologie médiévale, tome 20, pp. 253-317.

Pepin Eugene (1963). Gisors et la Vallee de l'Epte. Paris: Henri Laurens Editeur.

Seydoux Philippe (1979). Forteresses médiévales du nord de la France. In Revue du Nord, janvier-mars, tome 64, n. 252, pp. $217-218$

Sources matériaux cartographiques: gallica.bnf.fr / Bibliothèque Nationale de France.

Viollet-le-Duc Eugène ( I 854). Dictionnaire raisonné de l'architecture française du Xle au XVle siècle. Paris: B. Bance Editeur.Vol. I

\section{Author}

Marta Zerbini, Università degli Studi di Firenze, marta.zerbini@unifi.it

To cite this chapter: : Zerbini Marta (2020). L'impronta della dinamica storica dell'insediamento di frontiera: I'Epte in Normandia, Francia/The traces of historical dynamics in a border settlement: the study of Epte River in Normandy, France. In Arena A., Arena M., Brandolino R. G., Colistra D., Ginex G., Mediati D., Nucifora S., Raffa P. (a cura di). Connettere. Un disegno per annodare e tessere. Atti del $42^{\circ}$ Convegno Internazionale dei Docenti delle Discipline della Rappresentazione/Connecting. Drawing for weaving relationships. Proceedings of the 42th International Conference of Representation Disciplines Teachers. Milano: FrancoAngeli, pp. I 466- | 485 